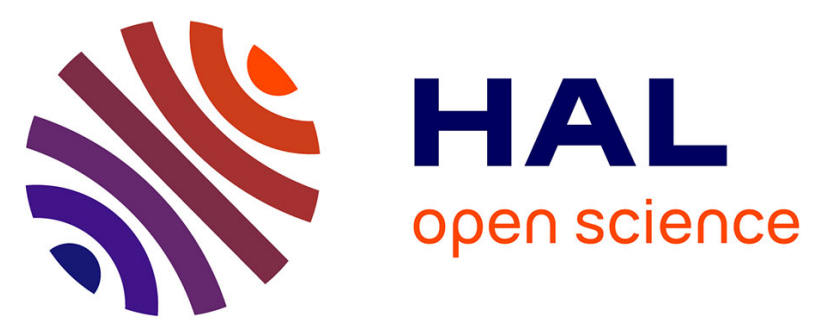

\title{
Durable response to a single dose of Anti D in immune thrombocytopenic purpura in an adult with underlying human immunodeficiency viral infection
}

Saman Hewamana, Chris Pepper, Kamaraj Karunanithi, Chris Jenkins, Clare Rowntree

\section{To cite this version:}

Saman Hewamana, Chris Pepper, Kamaraj Karunanithi, Chris Jenkins, Clare Rowntree. Durable response to a single dose of Anti D in immune thrombocytopenic purpura in an adult with underlying human immunodeficiency viral infection. Annals of Hematology, 2009, 88 (11), pp.1155-1156. 10.1007/s00277-009-0744-4 . hal-00535054

\section{HAL Id: hal-00535054 https://hal.science/hal-00535054}

Submitted on 11 Nov 2010

HAL is a multi-disciplinary open access archive for the deposit and dissemination of scientific research documents, whether they are published or not. The documents may come from teaching and research institutions in France or abroad, or from public or private research centers.
L'archive ouverte pluridisciplinaire HAL, est destinée au dépôt et à la diffusion de documents scientifiques de niveau recherche, publiés ou non, émanant des établissements d'enseignement et de recherche français ou étrangers, des laboratoires publics ou privés. 


\title{
Durable response to a single dose of Anti $D$ in immune thrombocytopenic purpura in an adult with underlying human immunodeficiency viral infection
}

\author{
Saman Hewamana - Chris Pepper • \\ Kamaraj Karunanithi • Chris Jenkins • Clare Rowntree
}

Received: 3 February 2009 /Accepted: 6 April 2009/Published online: 28 April 2009

(C) Springer-Verlag 2009

\section{Dear Editor,}

We report a case of steroid refractory human immune deficiency virus-related immune thrombocytopenic purpura (HIV-TP) successfully treated with single dose of intravenous Anti-Rh (Anti D). Although anti-retroviral treatment is the preferred first option in this situation, we treated him with steroids and, subsequently, with Anti D partly according to the patient's wishes. He showed a durable response (nearly 2 years now) to a single dose of treatment. We propose that Anti D should be considered before antiretroviral treatment, at least in some patients.

A 25-year-old man was referred to the haematology unit for further investigation of symptomatic thrombocytopenia. He had a known history of HIV infection for 5 years but has been asymptomatic till this point. The laboratory examination showed platelet count of $30 \times 10^{9} / \mathrm{L}$ with normal white cell count and haemoglobin. All other biochemical and haematological parameters were normal. The $\mathrm{CD}^{+} / \mathrm{CD}^{+}$count on peripheral blood was $450 / \mu \mathrm{L}$. On further investigations, the bone marrow aspirate showed

S. Hewamana $(\triangle) \cdot$ K. Karunanithi $\cdot$ C. Jenkins $\cdot$ C. Rowntree Department of Haematology,

University Hospital of Wales, Heath Park,

Cardiff CF14 4XW, UK

e-mail: hewamanas@cf.ac.uk

C. Pepper

Department of Haematology,

School of Medicine, University of Cardiff,

Cardiff CF14 4XN, UK increased megakaryocytes compatible with a diagnosis of peripheral consumption as the cause for low platelet count. A provisional diagnosis of ITP was made and he was treated with steroids without any response. A dose of Anti D gave an excellent initial response to the therapy, acquiring a platelet count of over $200 \times 10^{9} / \mathrm{L}$. Subsequently, the platelet count fluctuated between $185 \times 10^{9} / \mathrm{L}$ and $50 \times 10^{9} / \mathrm{L}$; but despite only having a single dose of therapy, he has been asymptomatic and did not need any further treatment. The variability of platelet count during the course of disease is illustrated on Fig. 1.

HIV is one of the many causes of secondary ITP. Thrombocytopenia was associated with AIDS even before the discovery of HIV [1]. While a number of different mechanisms have been reported by which HIV infection could produce thrombocytopenia, the ability of effective anti-retroviral therapy to improve platelet counts demonstrates a close association between HIV replication and thrombocytopenia. Probable mechanisms of thrombocytopenia include anti-platelet glycoprotein antibodies; antiHIV antibodies that cross-react with platelet membrane glycoproteins, platelet clearance due to immune complex disease and decreased platelet production/ineffective erythropoiesis. Thrombocytopenia is more common in patients with advanced HIV with CD4 lymphocyte count of less than $200 / \mu \mathrm{L}$ [2]. Interestingly, our patient had thrombocytopenia with normal CD4 count. HIV-TP has been shown to correlate with the degree of HIV viral load [3] and respond well to anti-retroviral treatment [4]. Hence, highly active anti-retroviral therapy (HAART) is considered as the first port of treatment [5]. Our patient did not agree with this option, so we had to consider either steroids, splenectomy, 


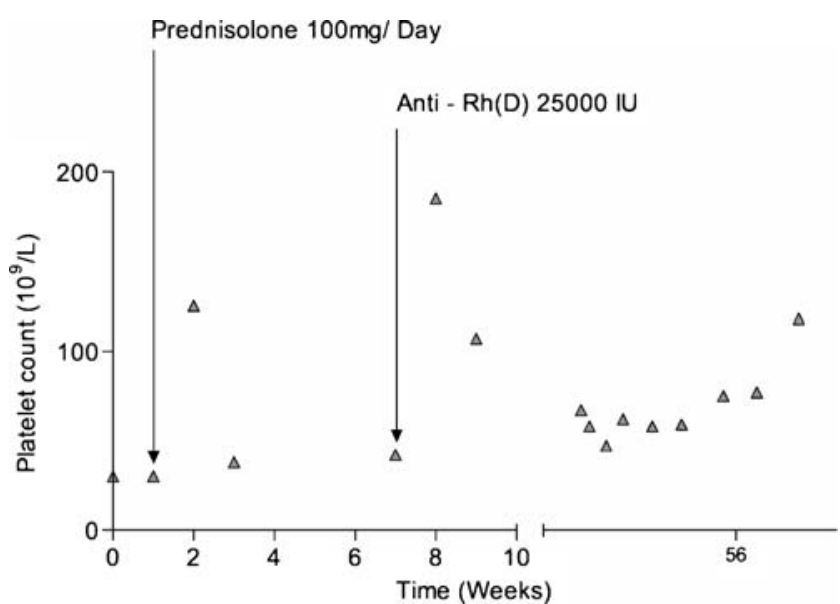

Fig. 1 Variability of platelet count during the course of disease

IVIg or Anti D. Anti D has been identified as an effective treatment in HIV-TP, but long-term remission after single dose is very rare. Our patient showed an excellent response to a single dose of Anti $\mathrm{D}$ and remained asymptomatic for nearly 2 years. This case illustrates the value of Anti D in gaining long-term remission in HIV-TP, and we propose Anti-Rh (Anti D) should be considered in at least selected patients before proceeding for HAART.

\section{References}

1. Morris L, Distenfeld A, Amorosi E, Karpatkin S (1982) Autoimmune thrombocytopenic purpura in homosexual men. Ann Intern Med 96:714-717

2. Kaslow RA, Phair JP, Friedman HB, Lyter D, Solomon RE, Dudley J, Polk BF, Blackwelder W (1987) Infection with the human immunodeficiency virus: clinical manifestations and their relationship to immune deficiency. A report from the Multicenter AIDS Cohort Study. Ann Intern Med 107:474-480

3. Servais J, Nkoghe D, Schmit JC, Arendt V, Robert I, Staub T, Moutschen M, Schneider F, Hemmer R (2001) HIV-associated hematologic disorders are correlated with plasma viral load and improve under highly active antiretroviral therapy. J Acquir Immune Defic Syndr 28:221-225

4. Landonio G, Nosari A, Spinelli F, Vigorelli R, Caggese L, Schlacht I (1992) HIV-related thrombocytopenia: four different clinical subsets. Haematologica 77:398-401

5. Scaradavou A (2002) HIV-related thrombocytopenia. Blood Rev 16:73-76. doi:10.1054/blre.2001.0188 